\title{
Efficacy of different instruments for the identification of the nursing diagnosis spiritual distress ${ }^{1}$
}

\author{
Erika de Cássia Lopes Chaves ${ }^{2}$ \\ Emilia Campos de Carvalho ${ }^{3}$ \\ Luiz Alberto Beijo 4 \\ Sueli Leiko Takamasu Goyatá \\ Sandra Cristina Pillon ${ }^{6}$
}

The study aims to identify the nursing diagnosis Spiritual distress in 120 patients with Chronic Renal Insufficiency, using different instruments, and to evaluate the effectiveness of these instruments in support of this identification. Data were collected separately by two nurses using a questionnaire containing sociodemographic information and the defining characteristics of Spiritual distress, as well as direct questioning to the patient regarding the presence of the diagnosis and the instruments: the Spirituality Rating Scale; Pinto and Pais-Ribeiro's Spirituality Scale; and the Spiritual Well-being Scale. The study found that $25.8 \%$ to $35.8 \%$ of the patients had the diagnosis. The diagnostic evaluation developed by the expert nurses presented no divergence between the two and obtained a perfect concordance coefficient (96.7\%) with the opinion of the patient; this demonstrated substantial concordance with the Existential Wellbeing Sub-scale (83.3\%) and with the Pinto e Pais-Ribeiro's Spirituality Scale (87.5\%), which demonstrated their usefulness for diagnostic identification.

Descriptors: Nursing; Nursing Diagnosis; Spirituality; Renal Insufficiency, Chronic.

\footnotetext{
${ }^{1}$ Paper extrated from doctoral dissertation "Revisão do diagnóstico de enfermagem Angústia Espiritual" presented to Escola de Enfermagem de Ribeirão Preto, Universidade de São Paulo.

2 RN, Ph.D. in Nursing, Adjunct Professor, Universidade Federal de Alfenas, MG, Brazil. E-mail: echaves@unifal-mg.edu.br.

${ }^{3}$ RN, Ph.D. in Nursing, Full Professor, Escola de Enfermagem de Ribeirão Preto, Universidade de São Paulo, WHO Collaborating Centre for Nursing Research Development, SP, Brazil. E-mail: ecdcava@usp.br.

${ }_{4}^{4}$ Mathematician, Ph.D. in Statistics and Agricultural Experiments, Adjunct Professor, Universidade Federal de Alfenas, MG, Brazil. E-mail: luizbeijo@unifal-mg.edu.br.

${ }^{5}$ RN, Ph.D. in Nursing, Adjunct Professor, Universidade Federal de Alfenas, MG, Brazil. E-mail: sueligoyata@yahoo.com.br.

${ }^{6}$ RN, Ph.D. in Nursing, Associate Professor, Escola de Enfermagem de Ribeirão Preto, Universidade de São Paulo, WHO Collaborating Centre for Nursing Research Development, SP, Brazil. E-mail: pillon@eerp.usp.br.
}

Corresponding Author:

Emilia Campos de Carvalho

Universidade de São Paulo. Escola de Enfermagem de Ribeirão Preto

Departamento de Enfermagem Geral e Especializada

Av. dos Bandeirantes, 3900

Bairro: Monte Alegre

CEP: 14040-902, Ribeirão Preto, SP, Brasil

E-mail: ecdcava@usp.br 


\section{Eficácia de diferentes instrumentos para a atribuição do diagnóstico de enfermagem sofrimento espiritual}

Neste estudo, visou-se identificar o diagnóstico de enfermagem sofrimento espiritual, em 120 pacientes com insuficiência renal crônica, utilizando-se diferentes instrumentos, e avaliar a eficácia de tais instrumentos no apoio dessa identificação. Os dados foram coletados separadamente, por dois enfermeiros, por meio de questionário contendo informações sociodemográficas e as características definidoras de sofrimento espiritual, além do questionamento direto ao paciente sobre a presença do diagnóstico e os instrumentos: escala de avaliação da espiritualidade, escala de espiritualidade de Pinto e Pais-Ribeiro e escala de bem-estar espiritual. O estudo encontrou que entre 25,8 e $35,8 \%$ dos pacientes possuíam o diagnóstico. A avaliação diagnóstica desenvolvida pelos enfermeiros peritos não apresentou divergência entre ambos e obteve coeficiente de concordância perfeito $(96,7 \%)$ com a opinião do paciente; essa demonstrou concordância substancial com a subescala de bem-estar existencial $(83,3 \%)$ e com a escala de espiritualidade de Pinto e Pais-Ribeiro $(87,5 \%)$ que demonstraram ser úteis para a identificação diagnóstica.

Descritores: Enfermagem; Diagnóstico de Enfermagem; Espiritualidade; Insuficiência Renal Crônica.

\section{Eficacia de diferentes instrumentos para la atribución del diagnóstico de enfermería sufrimiento espiritual}

El estudio tuvo por objetivo identificar el diagnóstico de enfermería Sufrimiento Espiritual en 120 pacientes con Insuficiencia Renal Crónica, utilizando diferentes instrumentos, y evaluar la eficacia de esos instrumentos en el apoyo de esta identificación. Los datos fueron recolectados separadamente por dos enfermeros, por medio de cuestionario conteniendo informaciones sociodemográficas y las características definidoras de Sufrimiento Espiritual, además del cuestionamiento directo al paciente sobre la presencia del diagnóstico y los instrumentos: Escala de Evaluación de la Espiritualidad; Escala de Espiritualidad de Pinto y Pais-Ribeiro; y, Escala de Bienestar Espiritual. El estudio encontró que $25,8 \%$ a $35,8 \%$ de los pacientes poseían el diagnóstico. La evaluación de diagnóstico efectuada por los enfermeros peritos no presentó divergencia entre ambos y obtuvo coeficiente de concordancia perfecto $(96,7 \%)$ con la opinión del paciente; esta demostró concordancia substancial con la Sub-escala de Bienestar Existencial $(83,3 \%)$ y con a Escala de Espiritualidad de Pinto y Pais-Ribeiro $(87,5 \%)$, que demostraron ser útiles para la identificación del diagnóstico.

Descriptores: Enfermería; Diagnóstico de Enfermería; Espiritualidad; Insuficiencia Renal Crónica.

\section{Introduction}

The NANDA-International (NANDA-I) has recognized Spiritual distress as a diagnosis relevant to nursing since 1980. Until the 2009 Brazilian version, the translated title of the diagnosis was Spiritual anguish, which was modified in the current version ${ }^{(1)}$. This diagnosis describes the congruence between values, beliefs and actions, within the domain called Life Principles, and has the definition: "Impaired ability to experience and integrate meaning and purpose in life through connectedness with self, others, art, music, literature, nature, and/or a power greater than oneself"(1). 
The manifestation of Spiritual distress among patients who live with the difficult experience of coping with Chronic Renal Insufficiency (CRI) and the arduous treatment of Hemodialysis (HD), defines the responses of these individuals to disorders that cover their spirituality. It is important that the nurse be alert to signs of Spiritual distress, as well as aspects related to its manifestation, since the presence of this diagnosis may worsen the physical and emotional symptoms and decrease the ability to face the disease ${ }^{(2)}$.

Despite all the developments in the field of nursing knowledge, studies on the diagnosis Spiritual distress have demonstrated that its concept still comprehends numerous complex and subjective issues that require articulated knowledge to include it as the focus of attention, which makes it a challenge for the nurse to cope with people who experience this suffering ${ }^{(3-5)}$. To assist in the accuracy of the nursing diagnoses, the use of instruments to make measurements of the phenomena evaluated has been recommended(6). The use of instruments aimed at the spiritual dimension can facilitate the exercise of diagnostic reasoning, facilitating the identification of Spiritual distress and allowing the narrowing of the possibilities of errors, since it is a diagnosis that involves a difficult to investigate subjective response. However, there is not a standardized instrument to evaluate the Spiritual distress of patients in the clinical environment ${ }^{(7)}$. Efforts have been employed in order to construct, or even translate and validate instruments that evaluate the phenomenon of spirituality, creating the need to investigate the efficacy of these instruments for the investigation of diagnoses involving the spiritual dimension. In the Brazilian scenario, three instruments were identified: the Spirituality Rating Scale(8), Pinto and Pais-Ribeiro's Spirituality Scale ${ }^{(9)}$ and the Spiritual Wellbeing Scale(10).

The Spirituality Rating Scale, originally called the Spirituality Self-Rating Scale (SSRS)(11) is a North American scale that reflects the orientation for spirituality of the individual, that is, whether they consider questions concerning the spiritual/religious dimension important and how they apply this in their life. It was created taking into consideration some items about religious practices and theoretical precepts of the Twelve Steps of Alcoholics Anonymous. Some of these precepts, which are not related to religious doctrine, refer to the belief that a Higher Power has a potential for recuperation, the need for recognition of personal failures and the need for spiritual practice. The scale consists of six statements, which have Likert type responses ranging from totally agree to totally disagree. For the calculation of the scores the inverse of the values of each item of the instrument are calculated and the responses of the six items are summed to produce the total score, which, in turn, represents the level of spiritual/religious orientation of the individual, with scores ranging from 6 to 30 , i.e. from the lower to higher level of spiritual/ religious guidance ${ }^{(11)}$. To make a comparison of scores, the means obtained in each group should be worked with and an appropriate statistical test applied to verify any differences between them.

Pinto and Pais-Ribeiro's Spirituality Scale $\mathrm{e}^{(12)}$ is an instrument consisting of five items centered on two dimensions: the vertical dimension, associated with the belief and the horizontal dimension, associated with hope/optimism, the aspect that gives meaning and significance in life due to the relationship with oneself, with others and with the environment. The responses are of the Likert type, given on a scale of four alternatives, from "do not agree" to "strongly agree". Regarding the determination of the scores, this is obtained by elementary statistical procedures, without inversion or transformation of values, thus the midpoint is 2.5 for each item. Therefore, when the scores assume a value above the midpoint, it can be affirmed that the dimension of spirituality is identified as relevant.

The Spiritual Well-being Scale ${ }^{(13)}$ consists of 20 items, answered on a Likert type scale of six points, ranging from "strongly agree" to "strongly disagree". It is divided into two sub-scales, in which ten items are intended for the evaluation of religious well-being and the others for the investigation of existential wellbeing(13). The scores of the two subscales are summed to obtain the overall measure of spiritual well-being. The authors of the scale(13) suggest the establishment of a cut-off score with the intervals from 20 to 40 for low spiritual well-being, 41 to 99 for moderate and 100 to 120 for high. In the two sub-scales, Religious and Existential Well-being, the ranges are 10 to 20, 21 to 49 and 50 to 60 points for low, moderate and high, respectively. The high scores are considered as positive spiritual well-being and the low and moderate scores as negative spiritual well-being(14-15).

This study aims to identify the nursing diagnosis Spiritual distress in patients suffering from Chronic Renal Insufficiency undergoing hemodialysis treatment and evaluated the efficacy of these previously mentioned instruments, in support of this identification. 


\section{Methods}

This is a descriptive study with a quantitative approach, performed in a renal therapy clinic located in the southern region of the State of Minas Gerais (Brazil). The service attends approximately 135 patients, with 130 in HD and five in Continuous Outpatient Peritoneal Dialysis. The criteria established for inclusion of the subjects were: to be a patient with CRI and undergoing HD, aged 18 years or more, to be oriented in time, space and person, able to express themselves verbally and to consent to participate in the study by signing the Terms of Free Prior Informed Consent. The Research Project was approved by the Ethics Committee of the School of Nursing of Ribeirão Preto/USP (Protocol No. 0810/2007), after formal consent to conduct the research from the Institution which manages the renal therapy clinic.

Data collection occurred in the first semester of 2008 and was performed during the hemodialysis sessions, after the clinical stability of the participants was confirmed, in order to make use of their time in the unit. It was chosen to collect data through an interview, considering the difficulty of the patient to fill in any instrument due to the immobilization of the arm during the treatment and the possibility of the subjects presenting visual difficulty and/or low level of instruction; therefore, the instruments on spirituality, even being all self-applied, were administered by the authors of the study themselves.

Considering that no reference to "gold standard" for evaluating spirituality was found in the literature, the determination of the presence of the nursing diagnosis Spiritual distress was carried out in two ways. First, this was carried out by two nurses who were considered experts, with experience in nursing diagnoses and who scored 8 to 10 points. According to the literature ${ }^{(6)}$ the experts must reach a minimum score of 5 points, acquired by means of specific criteria that reveal command of the area and nature of the study.

The expert nurses evaluated patients simultaneously, but separately, in order to identify the presence or absence of evidence of the referred diagnosis. A dichotomous questionnaire (presence/absence), containing all the defining characteristics of the nursing diagnosis Spiritual distress $^{(3)}$, favored the construction of the diagnostic reasoning, and was conducted independently by the nurses. As well as the clinical judgment conducted by the expert nurses, the presence of Spiritual distress was also determined by means of direct questioning of the patient, who, at the end of the interview, after seeing the definition of the diagnosis, confirmed its presence or absence. This form of research is based on the fact that the diagnosis approaches a subjective response, of an abstract and personal nature and, according to the literature ${ }^{(16-17)}$, this is the most appropriate way to conduct an approach to the spiritual experience, i.e. based on the individual's own description. Thus, the opinion of the patient regarding the presence of damage in the spiritual dimension can be a reference criterion for identifying Spiritual distress ${ }^{(7)}$. Therefore, the identification of the Spiritual distress nursing diagnosis was ensured in different ways: concordance between the expert nurses on the presence of the diagnosis; the opinion of the patient; low and moderate scores in the Sub-scale of Existential Well-being (the use only of the sub-scale of Existential Well-being was chosen, since the scale allows the separation of the religious aspects in the spiritual investigation); low spirituality score in Pinto and Pais-Ribeiro's Spirituality Scale; and low spirituality score in the Spirituality Rating Scale.

To tabulate and analyze the data the statistical program Statistical Package for the Social Sciences (SPSS) version 15 was used. Descriptive statistics allowed the description and summary of the data obtained. The Student's T test was employed to identify the correlation of the measurements obtained in the scales for the groups of individuals with and without the diagnosis under study. A value of $p \leq 0.05$ was considered significant. The reliability of the spirituality scales was evaluated by the internal consistency using the Cronbach's alpha. To verify the relationship between the nursing diagnosis Spiritual distress (presence or absence) and the score in each spirituality scale a logistic regression model was adjusted for each situation, which is appropriate for categorical response variables and describes the relationship between this response variable and a set of exploratory variables (co-variables) ${ }^{(18)}$.

The Kappa Analysis of Concordance was used to determine the reliability between the different criteria used in the identification of the diagnosis, establishing as a "reference" the subject's own confirmation. The interpretation of the concordance values measured by kappa followed the guidelines of the specialist literature, i.e.: kappa below 0: poor, 0 to 0.20 : mild; 0.21 to 0.40 : fair; 0.41 to 0.60 : moderate; 0.61 to 0.80 : substantial and 0.81 to 1.00 : perfect concordance ${ }^{(19)}$.

\section{Results}

A total of 120 patients participated in this study, whose ages ranged from 22 to 84 years with a mean age 
of 53 years ( $S D \pm 13.17$ years). Of the total, $50.8 \%$ were female, $52.5 \%$ married, $20 \%$ single, $10.8 \%$ widowed and the others divorced or separated $(16.7 \%)$. There was a prevailing low level of schooling, since it was observed that $10 \%$ of patients had never attended school and $57.5 \%$ had incomplete elementary education. When asked about religious beliefs (Table 1 ) and their practice, $72.8 \%$ of the patients responded that they participate in religious activities related to their belief, $23.3 \%$ did not participate and $4.2 \%$ did not respond.

Table 1 - Distribution of the study participants, according to religious belief and the importance of religion. Minas Gerais, Brazil, $2008(n=120)$

\begin{tabular}{lcc}
\hline \multicolumn{1}{c}{ Study variables } & n. & $\%$ \\
\hline Religious belief & & \\
Catholic & 95 & 79.2 \\
Evangelical & 15 & 12.5 \\
Without specified religion, but believes in God & 3 & 2.5 \\
Atheist & 2 & 1.7 \\
Spiritualist & 2 & 1.7 \\
Other & 3 & 2.5 \\
Importance of religion in life & & \\
Very important & 62 & 51.7 \\
Important & 28 & 23.3 \\
Somewhat important & 20 & 16.7 \\
Not important & 10 & 8.3 \\
\hline
\end{tabular}

This study found that $25.8 \%$ to $35.8 \%$ of patients investigated, considering the different criteria adopted, had the study diagnosis (Table 2).

Table 2 - Frequency distribution of the nursing diagnosis Spiritual distress in the study participants, according to the established criteria. Minas Gerais, Brazil, $2008(n=120)$

\begin{tabular}{lccccc}
\hline \multicolumn{1}{c}{ Established criteria } & \multicolumn{3}{c}{$\begin{array}{c}\text { Presence of Spiritual } \\
\text { Distress }\end{array}$} \\
& \multicolumn{3}{c}{ Yes } & \multicolumn{3}{c}{ No } \\
& n. & $\%$ & n. & $\%$ \\
\hline Opinion of the patient & 33 & 27.5 & 87 & 72.5 \\
Opinion of the expert nurses & 31 & 25.8 & 89 & 74.2 \\
Pinto and Pais-Ribeiro's Spirituality Scale & 40 & 33.3 & 80 & 66.7 \\
Existential Well-being Subscale & 43 & 35.8 & 77 & 64.1 \\
Spirituality Rating Scale & 8 & 6.7 & 112 & 93.3 \\
\hline
\end{tabular}

The diagnostic evaluations developed separately by two expert nurses presented no differences between them and obtained a correlation coefficient of "perfect" (Kappa: 0.92, p<0.001) with the patient's own opinion regarding the presence of the diagnosis, with $96.7 \%$ concordance observed. That is, among the 31 patients diagnosed with Spiritual distress by the nurses, 30 of them also said they have a diagnosis.

The Spirituality Rating Scale showed only $6.7 \%$ positive for the presence of the diagnosis Spiritual distress (Table 2), therefore it did not show efficacy in the identification of this diagnosis. This scale presented an overall Cronbach alpha of 0.74 , indicating a good value, however, lower than those obtained in the construction, which ranged from $\alpha=0.82 \%$ to $\alpha=0.91^{(11)}$ and in the validation of the Brazilian version $(\alpha=0.83)^{(8)}$. Pinto and Pais-Ribeiro's Spirituality Scale presented an overall Cronbach alpha of 0.81 , demonstrating significant internal consistency, with higher values than those achieved in the construction of the scale $(\alpha=0.74)^{(12)}$ and also in the validation of the scale in the Brazilian population $(\alpha=0.64)^{(9)}$ performed together with patients with CRI, also undergoing HD, similar to the present study. The Spiritual Well-being Scale presented an overall Cronbach alpha of 0.93 , and respectively, $\alpha=0.88 \%$ and $\alpha=0.93$ in the subscales of Existential Well-being and Religious Wellbeing. These results indicate a high degree of internal consistency, consistent with the general reliability index: $\alpha=0.92$, obtained in the Brazilian study ${ }^{(10)}$ and $\alpha=0.89$ achieved in the construction of the scale ${ }^{(13)}$.

Regarding the means for each scale used (Table 3), it was observed that Pinto and Pais-Ribeiro's Spirituality Scale and the Existential Well-being Sub-scale of the Spiritual Well-being Scale demonstrated greater efficacy in identifying the patients with the diagnosis, since the means presented were lower in those with the investigated phenomenon. Therefore, it was decided not to proceed with the evaluation of efficacy of the Spirituality Rating Scale, since it does not differentiate between individuals with the presence or absence of the nursing diagnosis of Spiritual distress, self-reported by the participants. 
Table 3 - Distribution of means obtained by the different scales, in reference to the presence and absence of Spiritual distress. Minas Gerais, Brazil, $2008(n=120)$

\begin{tabular}{|c|c|c|c|c|}
\hline Scales & Spiritual Distress & Mean & $\begin{array}{l}\text { Standard } \\
\text { Deviation }\end{array}$ & $p^{*}$ \\
\hline \multirow[t]{2}{*}{ Spirituality Rating Scale } & Presence & 18.42 & 3.50 & \\
\hline & Absence & 19.62 & 3.10 & 0.0710 \\
\hline \multirow[t]{2}{*}{ Pinto and Pais-Ribeiro's Spirituality Scale } & Presence & 12.97 & 3.44 & \\
\hline & Absence & 16.21 & 2.33 & 0.0001 \\
\hline \multirow[t]{2}{*}{ Existential Well-being Subscale } & Presence & 43.0 & 5.15 & \\
\hline & Absence & 54.25 & 8.29 & 0.0001 \\
\hline
\end{tabular}

* Student's t test.

To verify the relationship between the diagnosis of Spiritual distress and score of Pinto and Pais-Ribeiro's Spirituality Scale and of the Existential Well-being subscale of the Spiritual Well-being Scale, a logistic regression model was adjusted for each situation Figure 1 presents the graphs relating the score of the scales with the probability of diagnosis of Spiritual distress estimated by the model, in which it can be observed that, both Pinto and Pais-Ribeiro's Spirituality Scale (a), as well as the Existential Well-being Sub-scale (b) describe the diagnosis of Spiritual distress, since, as the scores of the scales increase, the probability of diagnosis decreases.

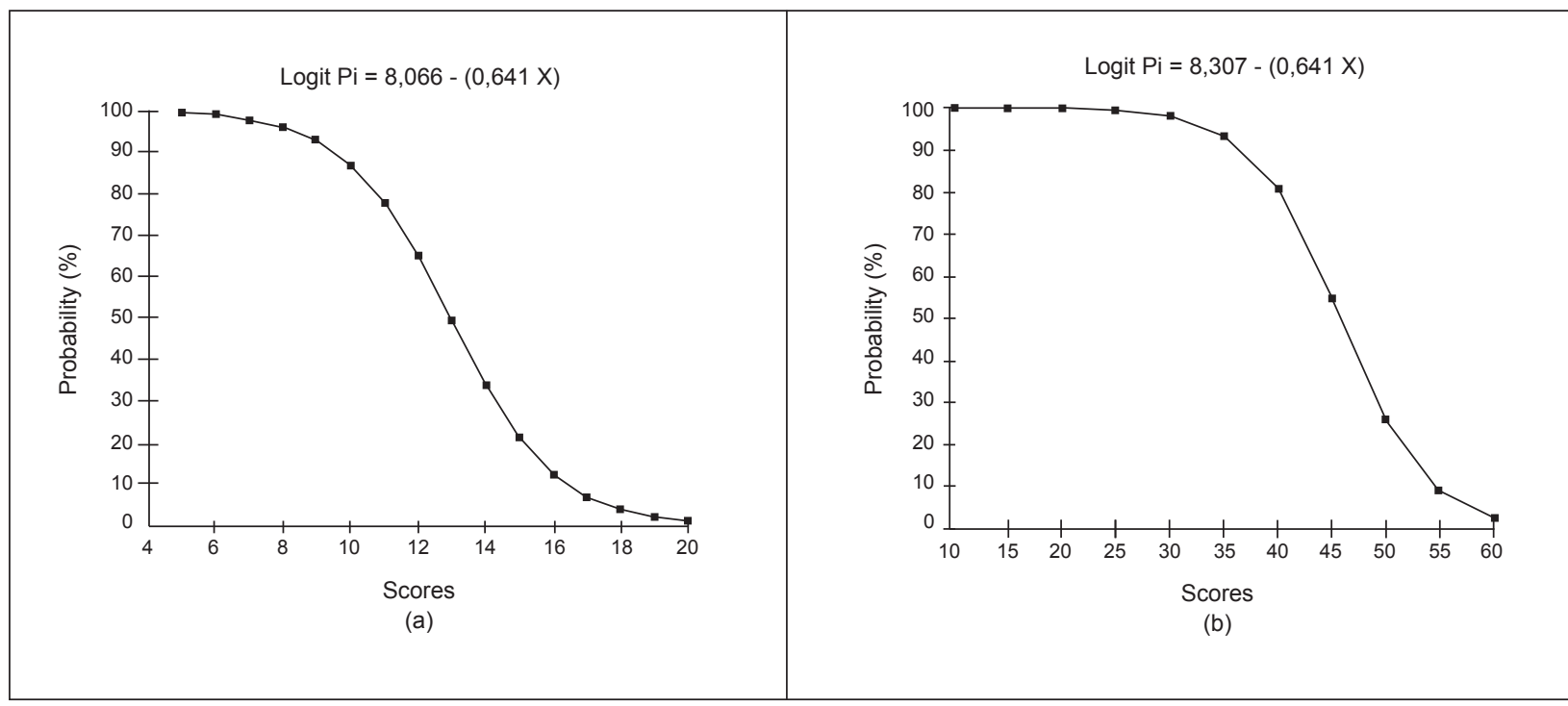

Figure 1 - Graphs of the logistic regression model adjusted for the score of Pinto and Pais-Ribeiro's Spirituality Scale (a) and the Existential Well-being Sub-scale of the Spiritual well-being scale (b)

Although the behaviors of both scales were apparently similar, it is important to note that in relation to the Spiritual Well-being scale, in this study, noting the recommendation of the literature(14-15), the high scores (with range between 50 to 60 points) were considered as positive spiritual well-being and moderate scores (with range of 21 to 49 points) and low (with the range of 10 to 20 points) as negative spiritual well-being which would therefore suggest the presence of the diagnosis Spiritual distress. However, the logistic regression model allowed the observation that the probability started to decrease from the score of 30 , i.e. patients who presented a score with a cutoff range between 20 and 30 (low existential well-being) had more than $99 \%$ probability of a diagnosis of Spiritual distress. Therefore, this score could more effectively ensure the presence of the diagnosis. Regarding Pinto and Pais-Ribeiro's Spirituality Scale, the authors ${ }^{(12)}$ do not suggest a cutoff score, however, in this study, the probability started to decrease from the score of 10 .

The results obtained with the use of Pinto and Pais-Ribeiro's Spirituality Scale showed statistically significant differences $(p=0.0001)$ between the subjects with and without Spiritual distress, confirming low 
spirituality in the patients with the diagnosis (Table 3 ). The concordance analysis between Pinto and PaisRibeiro's Spirituality Scale and the opinion of the patient regarding the presence of the diagnosis showed a kappa value of $0.71(p<0.001)$, with $87.5 \%$ concordance, i.e. "substantial concordance". Thus, through the scale it was possible to identify 29 out of the 33 patients who reported having the study diagnosis.

The scores obtained with the Spiritual Well-being Scale for the patients with the diagnosis of Spiritual distress were lower than those obtained by the individuals without the diagnosis, showing a statistically significant difference $(p=0.0001)$ between both groups of patients and confirming the existence of spiritual wellbeing and its non-existence in the first group (Table 3 ). The concordance analysis between the scores in the Existential Well-being Sub-scale and the opinion of the patient with $\mathrm{CRI}$ undergoing $\mathrm{HD}$, regarding the presence of spiritual distress, showed a kappa value of 0.62 $(p<0.001)$, with $83.3 \%$ concordance, i.e. "substantial concordance". Thus, through the scale it was possible to identify 28 out of the 33 patients who reported having the study diagnosis.

\section{Discussion}

To help the patient become aware of their spirituality and its influence in coping with chronic disease, it is crucial that nurses are able to recognize the nursing diagnosis of Spiritual distress and are aware of its manifestations, as these can result in an unsuccessful therapeutic plan, compromising the ability to cope with the disease and interfering with the positive outcome of their treatment ${ }^{(2,7,20-21)}$. In the present study, according to the patient's own opinion, 33 of them presented a diagnosis Spiritual distress. Also in another study ${ }^{(2)}$ on the spiritual perspectives of patients with advanced cancer and nonmalignant disease, the authors confirm that the patients are not only able to recognize their spiritual needs, but can also identify spiritual distress. However, many patients are reluctant to talk with health professionals about their feelings regarding spirituality due to the fear of stigmatization or the lack of interest of the team ${ }^{(22)}$. Therefore, it becomes important to establish a relationship of trust between the nurse-patient and to establish appropriate communication techniques.

Here, the nurses showed themselves open to the opinion of the patient regarding their spirituality, valorizing their judgment and allowing them to express their spiritual experience in the way it was being understood at the time, since the interview was centered on a personal response to the spiritual dimension. The diagnostic evaluation performed by expert nurses demonstrated a "perfect" concordance with the personal opinion of the patient, making it possible to infer not only that the criterion used as "reference" for the study proved to be adequate, but also that the interpretation of the nurses regarding the presence of the diagnosis was supported by the judgment of the patient.

Despite the inherent lack of nursing theoretical models to assist nurses in the investigation of the spiritual dimension(7), the proposed application of evaluation instruments for spirituality, as observed in this study, may facilitate the diagnostic reasoning, assisting in the search for clinical evidence of diagnoses directed towards this dimension. The results obtained by use of Pinto and Pais-Ribeiro's Spirituality Scale showed a "substantial" concordance with the opinion of the patient regarding the presence of the diagnosis, since low spirituality scores were observed in patients with Spiritual distress; therefore, this scale was shown to be suitable in the evaluation of the diagnosis, which supports the study of other researchers ${ }^{(12)}$, who highlighted the relevance of this in the investigation of spirituality in patients with chronic disease. The Existential Well-being Sub-scale of the Spiritual Well-being Scale was also shown to be relevant in the evaluation of the nursing diagnosis Spiritual distress, confirming another study(23), which identifies the scale as appropriate for the investigation of the diagnosis investigation. It is an instrument that evaluates the spiritual needs and well-being, making the nurse able to discern the Spiritual distress, for example, of emotional and psychosocial problems ${ }^{(23)}$.

Scholars ${ }^{(24)}$ have argued that the traditional method of spiritual support was to have a chaplain or religious person available, however, today the nurse can offer systematic spiritual care, through the investigation and evaluation of the human responses to this dimension. Although, among the reasons for omission of spiritual care, is the consideration that the issue is unscientific and that there is a lack of training for spiritual care(7), it must be recognized that the NANDA Taxonomy II-I ${ }^{(1)}$ contemplates the phenomenon and that, in turn, this classification system allows the focus of the nursing process to be directed, facilitating the making of decisions regarding the care. Finally, instruments for evaluating spirituality, as well as the opinion of the patient, are useful tools for the identification of a nursing diagnosis as complex as Spiritual distress. In this sense, the use of different criteria for confirming the diagnosis 
becomes important in order to increase the precision of the diagnostic identification.

\section{Conclusion}

The prevalence of the nursing diagnosis Spiritual distress in patients with CRI undergoing $\mathrm{HD}$, ranged from $27.5 \%$ to $35.8 \%$, considering the different criteria adopted which, in turn, presented satisfactory concordance with the opinion of patients regarding their spirituality. The relevance of these results is the fact that this group of patients presents important conflicts in the spiritual dimension, which can compromise the ability to deal with kidney disease and its treatment. This study revealed the importance of nurses considering the opinion of patients about their spirituality and also of the use, in the clinical environment, of different instruments for the evaluation of Spiritual distress, which proved to be conducive to the process of diagnosis formulation. Among the instruments used to investigate the spiritual dimension of patients, which showed satisfactory efficacy were Pinto and Pais-Ribeiro's Spirituality Scale and the Existential Well-being Sub-scale of the Spiritual Wellbeing Scale. Importantly, the choice of these instruments should consider important factors for the clinical practice as well as the ease of use, the simplicity of comprehension and the limited time for their operation, while reflecting the dynamic nature of nursing diagnoses. Therefore, the instrument should prove to be useful for clinical practice, with a rapid application and an ability to identify the presence of the investigated phenomenon.

The use of various approaches for the evaluation of spirituality, as employed in this study, extends the range of possibilities for the identification of diagnoses related to the spiritual dimension, ensuring, for the patient with CRI, nursing care from a holistic perspective. It is necessary to consider that the nursing literature has been devoted increasingly to the study of Spirituality and therefore new instruments may arise that can represent the phenomenon under investigation. The subjectivity of the research theme represents a limitation of the study, which leads to new studies on the nursing diagnosis Spiritual distress in other populations, with wide samples and which promote the generalization of results being considered important.

\section{References}

1. NANDA. Diagnósticos de enfermagem: definições e classificação, 2009-2011. Porto Alegre (RS): Artmed; 2010.
2. Grant E, Murray SA, Kendall M, Boyd KJ, Tilley S, Ryan D. Spiritual issues and needs: perspectives from patients with advanced cancer and nonmalignant disease. A qualitative study. Palliative Support Care. 2004;2(4):371-8.

3. Chaves ECL, Campos EC, Goyatá SL, Galvão CM. Spiritual distress: integrative review of literature. Online Braz J Nurs. [Internet]. 2008. [acesso 31 maio 2010]; 7(2). Disponível em: http://www.uff.br/objnursing/index. php/nursing/article/view/j.1676-4285.2008.1551/358.

4. Chaves ECL, Campos EC, Terra FS, Souza L. Clinical Validation of Impaired Spirituality in Patients with Chronic Renal Disease. Rev. Latino-Am. Enfermagem. [Internet]. 2010. [acesso 21 agosto 2010]; 18(3): [09 telas]. Disponível em: http://www.eerp.usp.br/rlae

5. Chaves ECL, Campos EC, Hass VJ. Validação do diagnóstico de enfermagem Angústia Espiritual: análise por especialistas. Acta Paul Enferm. 2010;23(2):264-70.

6. Fehring RJ. The Fehring model. In: Carroll-Johnson RM, Paquette CJ, editors, Classification of Nursing Diagnosis. $10^{\mathrm{a}}$ conference of North American Nursing Diagnosis Association; 1994; Philadelphia: Lippincott; 1994. p. 55-7.

7. Villagomeza LR. Spiritual distress in adult cancer patients: toward conceptual clarity. Holist Nurs Pract. 2005;19(6):285-94.

8. Gonçalves MAS, Pillon SC. Adaptação transcultural e avaliação da consistência interna da versão em português da Spirituality Rating Scale (SSRS). Rev Psiquiatr Clín. 2009;36(1):10-5.

9. Chaves ECL, Carvalho EC, Dantas RAS, Terra FS, Nogueira DP, Souza L. Validação da Escala de Espiritualidade de Pinto e Pais-Ribeiro em pacientes com insuficiência renal crônica em hemodiálise. Rev Enferm UFPE. [Internet]. 2010. [acesso 21 maio 2010]; 4(2):268-74. Disponível em: http://www.ufpe.br/revistaenfermagem/index.php/ revista/article/view/890

10. Marques FL. A saúde e o bem-estar espiritual em adultos Porto-alegrenses. [Tese de Doutorado]. Porto Alegre (RS): Faculdade de Psicologia da Pontifícia da Universidade Católica do Rio Grande do Sul; 2000. 179 p. 11. Galanter M, Dermatis H, Bunt G, Williams C, Trujillo $M$, Steinke P. Assessment of spirituality and its relevance to addiction treatment. J Substance Abuse Treat. 2007;3(1):257-64.

12. Pinto C, Pais-Ribeiro JL. Construção de uma escala de avaliação da espiritualidade em contextos de saúde. Arq Med. 2007;21(2):47-53.

13. Paloutzian R, Ellison C. Loneliness, spiritual well-being and the quality of life. In: Peplau D, Perlman D. Loneliness: a sourcebook of current theory, research and therapy. New York: John Wiley; 1982. p. 224-35. 
14. Gastaud MB, Souza LDM, Braga L. Bem-estar espiritual

e transtornos psiquiátricos menores em estudantes de Psicologia: estudo transversal. Rev Psiquiatria. 2006;28(1):12-8.

15. Volcan SMA, Sousa PLR, Mari JJ, Horta BL. Relação entre bem-estar espiritual e transtornos psiquiátricos menores: um estudo transversal. Rev Saúde Pública. $2003 ; 7(4): 440-5$.

16. Bash A. Spirituality: the emperor's new clothes? J Clin Nurs. 2004;13(1):11-6.

17. Miner-Williams, D. Putting a puzzle together: making spirituality meaningful for nursing using an evolving theoretical framework. J Clin Nurs. 2006;15(7):811-21.

18. Agresti A. Categorical data Analysis. New York: John Wiley \& Sons; 1990. 576 p.

19. Rosner B. Fundamentals of Biostatistics. 6.ed. Belmont: Thomson Higher Education; 2006.

20. Saad M, Masiero D, Battistella LR. Espiritualidade baseada em evidências. Acta Fisiátrica. 2001;8(3):10712.

21. Davis LA. A phenomenological study of patient expectations concerning nursing care. Holistic Nurs Practice. 2005;19(3):126-33.

22. Loh KY. Spiritual distress in a terminally ill patient with breast cancer. Int J Palliative Nurs. 2004;10(3):131-2.

23. Elerhorst-Ryan JM. Instruments to measure spiritual status. In: Spilker B. Quality of life and pharmacoecnomics in clinical trials. Philadelphia: Lippincott-Raven; 1996. p. 145-53.

24. Cavendish R, Luise BJ, Horne K, Bauer M, Medefindt J, Gallo $M$, et al. Opportunities for enhanced spirituality relevant to well adults. Nurs Diagn. 2000;11(1):151-67. 